\title{
Crucial Issues with Legal Protection of Consumers Human Rights when Banks unilaterally Close Accounts
}

\author{
By Aleksejs Jelisejevs
}

\begin{abstract}
When unilaterally closing a customer's account due to so-called de-risking, the customer's interests are not only ignored by the bank but their human rights, including respect for his private life and presumption of innocence, are also severely violated De facto, de-risking stigmatizes discarded consumers as being involved in criminal activity without a court conviction. As a result of the unfair account closure, both the consumer's social and psychological integrity can suffer. Their rights to establish and develop relationships with other human beings and the outside world and respect for reputation are put in jeopardy. In order to overcome the above collision of interests, this study proposes a doctrinal assessment of consumer's interests that should limit the bank's right to unilaterally terminate the contract by the systemic and teleological interpretation of regulating rules in combination with the general civil principle of good faith. By analogy with the original source of the problem, this tool has been called the "Good Faith-Based Approach". Therefore, in view of states' affirmative obligations under the European Convention on Human Rights, this research shows that the consumers' conflicting interests should take priority in legal protection until the consumer's involvement in money laundering and terrorist financing is established and proven. A certain level of restrictions imposed on the consumers' fundamental rights could be considered justifiable to prevent money laundering as long as the business relationship with the bank continues. However, when rupturing contractual relations within the de-risking paradigm, only close adherence to the good faith principles can guarantee that the bank's rights are not applied by the bank formally and unreasonably, that is, against the sense, meaning, and goals established by the regulating authorities or contrary to the general idea of law.
\end{abstract}

Keywords: Good faith, De-risking, Bank account closure, Unilateral termination of contract, Human rights

\section{Introduction}

Over the past years, large-scale bank account closure has acquired a systemic character and become an absolute public problem. While the cause of banks' actions could originate from a complex combination of factors, herein, money laundering risks clearly prevail. On the whole, the overzealous account closure is motivated by a Risk-Based Approach was introduced by the Financial Action Task Force (FATF) and included in financial sector regulations for almost all states, including the EU and Latvia as well. In short, it implies anti-money laundering

"PhD Candidate in Law Science, Turïba University, Riga, Latvia. E-mail: aleksejs@jelisejevs.lv. 
(AML) measures and combating the terrorism financing (CTF) risks to ensure the mitigation of these risks.

At the same time, unfortunately, this approach most often leads to so-called "de-risking," defined as an action taken by a payment service provider to avoid risk or, in practice, as the action is taken without assessing considering alternative avenues to mitigate this risk. Simply put, it means that banks are closing accounts at any hint of risk instead of trying to minimise this risk.

From the viewpoint of legal regulations, in this case, we are talking about the unilateral termination of the payment account contract by the bank against the will of the payment service user. And, of course, legal rules allow banks, like any other private business, to choose their customers ${ }^{1}$.

This problem is recognised at various levels. For example, the Australian professor of law Louis de Koker, who specialises in these matters, notes that "derisking is a situation when the bank may reduce risk by closing accounts while actually increasing the risks for society" ${ }^{\prime 2}$. Adam Szubin from US Treasury formulated that "de-risking is problematic. Financial institutions terminate relationships without careful examination of the risks. They do not use available tools to manage them" ${ }^{3}$. Latvian politicians and statesmen recognise this issue as well. Mārtinšs Kazāks, the president of Bank of Latvia, has admitted that in many cases Latvian banks are choosing not to manage risk but to avoid it ${ }^{4}$. Prime Minister Krišjānis Karinš notes - the Latvian financial sector should start to focus more on risk management than to avoid any risk" ${ }^{5}$. At last, the FATF has concluded that "Derisking should never be an excuse for a bank to avoid implementing a risk-based approach, in line with the FATF standards"6.

As we can see, most of this discussion is political, financial and commercial. But few stakeholders have analysed the legal side of this question. In general, the "thought leadership" monopoly on this legal issue has been established by the banks, who were convinced that they are free to act as they wish. On the other hand, the doctrine on this matter is silent, and the universal case-law has not been formed yet. That is why it is critical to attempt to establish a scientific method to protect the rights of payment service consumers when banks unilaterally terminate account relationships.

Although the EU authorities have attempted to protect consumers' interests from arbitrary actions of banks, including a directive to guarantee of access to payment services via accounts with basic features, the human rights of the consumer, who has been rejected by the bank, remain deadlocked in the formal application of the legal norms that allow the banks to terminate their contractual relationships with a customer as long as they simply give proper notice. In order to overcome the above collision, I am proposing a doctrinal approach according to which the bank's right to withdraw from the contract unilaterally should be limited

\footnotetext{
${ }^{1}$ See, for example, the two UK cases of Dahabshiil Transfer Services Ltd v Barclays Bank Plc and Harada Ltd and another v Barclays Bank Plc.

${ }^{2}$ De Koker, Sindh \& Capal (2017) at 119.

${ }^{3}$ Adam Szubin (2016).

${ }^{4}$ Kazāks (2020).

${ }^{5}$ Kariňš (2020).

${ }^{6}$ FATF (2014).
} 
by the systemic and teleological interpretation of regulating rules in combination with the general civil principle of good faith which, by analogy with the original source of the problem, is called "Good Faith-Based Approach"?

Under the general principle of good faith, everyone should exercise his subjective rights considering the reasonable interests of others. In my previous research, I have tried to frame general measures of my Good Faith-Based Approach for these issues as follows: 1) respect for freedom of contract and valid reasons for intervention in private autonomy; 2) an assessment of the interests of both the bank and the consumer to measure whose interests have priority and should be protected in this situation according to the purpose of the law and the circumstances of the particular case; 3) objective incompatibility of results of applying a specific legal norm or transaction with the sense, meaning, and goals of regulating the relevant legal relationship or the general idea of law, including from the viewpoint of justice and public interests; 4) the bank using its subjective rights in a form formally consistent with the letter of law or the text of legal transaction but contradicting their true goals and meaning, as well as does not take into account the interests of the consumer.

Within the framework of several subsequent works, I intend to analyse in detail each of these aspects, but the subject of this paper is a doctrinal assessment of consumer's interests as a part of my research. On the whole, this analysis is inherently applicable to any national legal system transposing EU rules with respect to this matter, but its ground refers to the legislation, legal doctrine, and case law of Latvia.

My research is based on qualitative methods of scientific analysis, within the framework of which my original working hypothesis had served as the foundation for data acquisition. The data then was described, characterised and attributed to what, in turn, became a cause for correction and refinement of this hypothesis in order to build and express a scientific theory, based on which the comprehensive research document has been created. Consequently, a hypothetico-deductive model was employed as a principal toolkit to elaborate the doctrine. At the same time, I believe that comparative legal and system structure analysis methods assisted my argument in favor of this approach, within which the doctrinal interpretation and construction have been made to broaden the scope of the general good faith principle to this issue.

\section{Interest Assessment within Good Faith}

According to Latvian legal doctrine ${ }^{8}$ and its case-law ${ }^{9}$, the main purpose of the good faith principle is to preclude the person from exercising the subjective right which formally resides with him if the conflicting interests of the opposing

\footnotetext{
${ }^{7}$ Jelisejevs (2021).

${ }^{8}$ Krons (1937) at 141.

${ }^{9}$ Latvian Supreme Court's judgments: in case No.SKC-540 at p.5; in case No. SKC-75 § 13(6); in case No. SKC-259/2019 § 7.1 (2); in case No. SKC-1782/2018 § 6.5 (2) and in case No. SKC-231/ $2020 \S 6.2(7)$.
} 
party to the legal relationship take priority under the legislative goal and circumstances of the particular case. Therefore, in each specific case, based on an objective assessment of the parties' interests, the court should determine whose interests are to be protected ${ }^{10}$. This becomes clear as a result of the correlation of specific legal norms regulating the interests of each party with the good faith rule (e.g., Art. 1 of the Latvian Civil Law), that is, through their systemic interpretation, which, in turn, is allowed only in those exceptional occurrences when the result of the application of these legal norms will be utterly unfair for one of the parties ${ }^{11}$. In such circumstances, an abstract solution for the conflict of interest formulated in the legal norms is fundamentally different from the actual features of the variance of parties' interests in the particular legal relationships in real life ${ }^{12}$. At the same time, the task of good faith is by no means considered to protect the socially weak side of the transaction per $\mathrm{se}^{13}$. However, the Good Faith-Based Approach can become the foundation to restore the interests of the transaction party, which is objectively in a weaker position in the view of legal regulation.

According to the approach adopted by the Court of Justice of the European Union ${ }^{14}$ confirmed by the case-law of Latvia ${ }^{15}$, the consumer is a priori recognised as the less protected side of the contractual relationships vis-à-vis the supplier because he is forced to agree to transaction terms drawn up in advance by the supplier without being able to influence the content of these terms. That is why the good faith principle requires any supplier not to use the consumer's lack of experience as well as his weaker position regarding both his bargaining power and his level of knowledge ${ }^{16}$.

Thus, in civil circulation, the unequal position of the consumer and the service provider has an objective character and is not associated with the subjective characteristics of the parties in particular legal relationships ${ }^{17}$. The weaker position of the consumer in contractual relations demands replacing the formal balance which has been established between the rights and obligations of the parties with an effective balance that re-establishes equality between them ${ }^{18}$. Consequently, when regulating any legal relationship with a consumer's participation, the purpose of the law is to effectively restore the real equality of the parties through the priority protection of the consumer's interests with a more critical attitude towards the exercise of the service provider's rights. There is no doubt that the same

\footnotetext{
${ }^{10}$ Balodis (2002) as well as Latvian Supreme Court's judgments: in case No. SKC-259/2019 § 7.4 (5) and in case No. SKC-363/2017 § 11 (2).

${ }^{11}$ Latvian Supreme Court's judgment in case No. SKC-231/2020 § 6.1 (4 and 4) as well as Krons (1937) at 300 .

${ }^{12}$ Krons (1937) at 293; Balodis (2002) at 282.

${ }^{13}$ Balodis (2007) at 148.

${ }^{14}$ See, e.g., Judgments of the Court of Justice of the European Union: in cases No. C-240/98 - C$244 / 98 \S 25$; in case No. C-168/05 $§ 25$; in case No. C-243/08 $\$ 22$.

${ }^{15}$ Latvian Supreme Court's judgments in case No. SKA-59 § 12 (2) and in case No. SKC-154/2017 $\S 7(2)$.

${ }^{16}$ Vítolina (2015) at 98.

${ }^{17}$ Latvian Supreme Court's judgment in case No. SKA-59 § 12 (3).

${ }^{18}$ Judgments of the Court of Justice of the European Union in No. C-168/05 § 36 and in No. C-243/ $08 \S 25$.
} 
approach should be presumed in the contractual relationship between the bank and the client with a consumer status.

Moreover, if a payment service provider uses its subjective rights to unilaterally close payment accounts within the framework of the de-risking policy, that is, in order to refuse any risks connecting with services for some consumer, the protection of the consumer's interests from unfair behavior of the provider has an even higher priority. This assertion follows from the fact that the objective weakness and actual inequality of a bona fide consumer in such legal relations are even more evident. Analysing the bank activity in the scope of combating money laundering and terrorism financing, the Latvian Constitutional Court stated that "if a person is not engaged in terrorism financing or money laundering, then he is not able to foresee at all what exactly could be doubts and, at the same time, cannot predict what documents and information he would have to submit in order to prevent these doubts"19. As a consequence, in the case when to avoid the risk of terrorist financing and money laundering, a bank unilaterally withdraws from an agreement with a client who, as a matter of fact, is not engaged in the financing of terrorism and money laundering the priority protection should be provided to the interests of this client who has no natural ability to predict the exact nature of situations the bank could consider risky in order to avoid them ${ }^{20}$.

\section{De-risking v. Human Rights}

Analysing the balance between conflicting interests of customers and banks relating to unilateral closure of accounts under the de-risking policy, we certainly need to stress that the consumers' access to payment services within the EU internal market is being recognised by European institutions as a tremendously important issue in respect of their legal protection and several special EU regulatory enactments $^{21}$ were aimed at harmonizing the national law of its members, taking into account some general principles. As a part of this legal regulation, we can note the exclusion of any discrimination against consumers legally residing in the EU because of their nationality or place of residence or any other grounds referred to in Article 21 of the Charter of Fundamental Rights of the European Union ${ }^{22}$. At the same time, there is the postulation of uneven positions of consumers and undertakings with their unalike needs for the protection level and specific guarantees for consumer rights ${ }^{23}$, including access to payment accounts with basic features ${ }^{24}$.

\footnotetext{
${ }^{19}$ Latvian Constitutional Court's judgment in case No. 2008-47-01 $§ 14.2$.

${ }^{20}$ Ibid.

${ }^{21}$ Directive 2014/92/EU and Directive (EU) 2015/2366.

${ }^{22}$ Art. 15 of Directive 2014/92/EU.

${ }^{23}$ Preambular paragraph 53 of Directive (EU) 2015/2366.

${ }^{24}$ One of the elements of safeguarding the rights of payment service users became the introduction into civil intercourse of a payment account with basic features, access to which should be ensured irrespective of the consumers' financial circumstances, such as their employment status, level of income, credit history or personal bankruptcy (see Preambular paragraph 35 of the Directive 2014/ 92/EU, which was transposed into Latvian Law on Payment Services and Electronic Money via the
} 
Moreover, the universal requirement of the pan-European legal regulation for payment services is the unconditional primacy of the fundamental rights and principles recognised by the Charter of Fundamental Rights of the European Union $^{25}$ that is mandatory for the domain of combating money laundering ${ }^{26}$ as well. It means that transposed into national legislation (including payment service ${ }^{27}$ and anti-money laundering ${ }^{28}$ laws), these directive rules, inter alia, prescribe the necessity to respect private and family life ${ }^{29}$, protect personal data ${ }^{30}$, and honor the presumption of innocence ${ }^{31}$. They also require respecting the freedom to conduct business 32 .

Beyond doubt, all these safeguards relate, first of all, to ensuring the interests of payment service consumers. Still, only the postulate of the freedom to conduct business can apply to the interests of credit institutions as well. At the same time, the European legislator has clearly defined that the legal provisions against utilisation of the financial system for illegal purposes such as fraud, money laundering, or terrorism financing must not be used as a pretext for rejecting commercially less attractive consumers ${ }^{33}$. Consequently, it is in matters of termination of contractual relations with an invocation to the money laundering risks that payment providers' interest in the free conduct of business is normatively limited.

\section{Presumption of Innocence}

At that, the bank's refusal to do business with its client due to the increased risk of money laundering and terrorist financing can reasonably be regarded as stigmatizing the customer as being involved in criminal activity. Indeed, money laundering and terrorism financing (as they have been defined, for example, by Article 5 of the Latvian AML Law) are undoubtedly criminal offenses. It follows

Law of 2 March 2017). Nevertheless, this legal tool cannot be considered exhaustive. It should not exclude other legal protection against unfair actions of payment service providers, if only because most of the provisions of the EU directives relating to this regulation subject matter are universal and apply to all types of payment services. In particular, according to preambular paragraph 53 of Directive (ES) 2015/2366, its core provisions should always apply, irrespective of the user's status. In turn, Article 15 of Directive 2014/92/EU prohibits discrimination against consumers when gaining access to any payment account within the European Union. Thus, by implementing the payment account with basic features, the legislator, per contra, emphasized the priority for protecting the interests of each consumer of any payment services over their suppliers.

${ }^{25}$ See, for example, preambular paragraph 90 of the Directive (EU) 2015/2366; preambular paragraphs 35, 55 and Article 15 of the Directive 2014/92/EU.

${ }^{26}$ Preambular paragraph 65 of Directive (EU) 2015/849.

${ }^{27}$ In Latvia it is the Law on Payment Services and Electronic Money (see Informative Reference to European Union Directives, $\S \S 3$ and 4)

${ }^{28}$ In Latvia it is the Law on the Prevention of Money Laundering and Terrorism and Proliferation Financing (see Informative Reference to European Union Directives, $\S \S 1$ and 5).

${ }^{29}$ Art. 7 of the Charter.

${ }^{30}$ Art. 8 (1) of the Charter.

${ }^{31}$ Art. 48 (1) of the Charter.

${ }^{32}$ Art. 16 of the Charter.

${ }^{33}$ Preambular paragraph 34 of Directive 2014/92/EU. 
that the bank's departure from the business relationship with the client because of money laundering and terrorist financing risks in itself means that the bank suspects this client of possible involvement in these offenses or, at least, admits such a possibility.

At any rate, all of the above implies that the bank treats such a client as a person committing or preparing to commit a crime. However, the general tenet runs that until a person's guilt in committing a crime is recognised under the law, treating this person as if it is proved that he has committed this criminal act is contrary to the presumption of his innocence ${ }^{34}$. Of course, the presumption of innocence, being a fundamental human right, manifests itself primarily in criminal proceedings ${ }^{35}$. Nevertheless, according to the conclusions of the European Court of Human Rights (hereinafter abbreviated as ECHR) supported by the Constitutional Court of Latvia, in general, this presumption forms the content of the right to a fair trial in the broadest sense, including also in determining the civil rights and obligations of the concerned person ${ }^{36}$.

It is also evident that the presumption of innocence is not absolute and per se does not prohibit establishing restrictions to a person if such is necessary for reaching a respective legitimate aim $^{37}$. Such restriction could be justified only with proportionality with the aim to be reached, that is assessed by 1) appropriateness (whether it is possible to reach the legitimate aim by means of the measure selected); 2) necessity (whether the legitimate aim could be reached by other measures that would restrict the rights of a person at a lesser extent), and 3) compliance (whether the benefit gained by the society is greater than the detriment done to the rights of a person) ${ }^{38}$.

In another part of my research, which concerns analysing the banks' interests under the Good Faith-Based Approach, I have thoroughly analysed the proportionality issues in the course of a bank's unilateral closure of consumer's payment account. I will herein only point out that banks' withdrawal from contractual relationships with consumers due to de-risking is in itself unsuitable for achieving legitimate goals concerning anti-money laundering and terrorist financing. In fact, such actions on the part of financial institutions can indirectly contribute to the commission of such crimes ${ }^{39}$. On the other hand, the stated aims of combating money laundering and terrorist financing can definitely be achieved by other legal instruments that are less destructive for the consumer's rights, including updating information regarding him and overseeing his activities to ensure that his transactions are not considered suspicious.

But for all that, there can be no doubt with respect to compliance with the public interests when deviating from the absolute presumption of the innocence of the payment service consumers within the risk-based approach since this deviation has a legitimate aim to counteract serious crimes. Nevertheless, relevant state

\footnotetext{
${ }^{34}$ See, e.g., Latvian Constitutional Court's judgment in case No. 2005-22-01 § 5.1.

${ }^{35}$ See, e.g., Latvian Constitutional Court's judgment in case No. 2012-15-01 $§ 15.1$.

${ }^{36}$ See, e.g., Latvian Constitutional Court's judgment in case No. 2015-25-01 $\$ 13$ (5).

${ }^{37}$ See, e.g., Latvian Constitutional Court's judgment in case No. 2005-22-01 $\$ 5.1$.

${ }^{38}$ See, e.g., Latvian Constitutional Court's judgment in case No. 2010-38-01 $§ 11$.

${ }^{39}$ See, e.g., FATF (2014); de Koker (2011) at 361 and 368; McKendry (2014); Durner \& Shetret (2015) at 19 .
} 
authorities are to ensure that risk assessment in the context of customer due diligence is carried out by the payment service providers without discrimination based on any ground ${ }^{40}$. Hence, by analogy (extra legem) with EU legal regulation of politically exposed person issues the risk-based approach regarding high-risk consumers should be of a preventive and not criminal nature. That is why there are quite justified reasons to limit the high-risk consumers' presumption of innocence in the due diligence process against them while their business relationship with payment service providers remains active. But if the provider terminates contractual relations with any such consumer based on this risk, then it is directly contrary to the letter and spirit of anti-money laundering regulation.

Furthermore, within the framework of civil relations, when fundamental human rights are being restricted based on the decision of a private person, for instance, a credit institution, rather than that of a public authority, then the consequences caused by its mistaken decision affect an individual more gravely than if the decision on this issue was made by public authorities ${ }^{41}$. When unilaterally closing a payment account due to money laundering and terrorist financing risk, that is, de facto presuming the client's possible culpability in these criminal offenses, a bank a priori has access to less information than state institutions. At the same time, the bank never seeks to assess whether the benefit gained by society if its suspicions turn out to be grounded in reality in proportion with the inflicted on a consumer's interests if the bank's suspicions prove to be incorrect. Besides, in order to avoid responsibility for its treatment of clients in such a way as if it has already been proven that the clients have committed or plans to commit these crimes, the payment service providers, as a rule, mask their true intentions behind an abstract right to terminate business relationships without providing reasons.

Therefore, we need to stress that under the good faith requirement, if some payment service provider withdraws from contractual relations with a consumer by direct or indirect reason of de-risking, the consumer's interests should be without fail analysed from the standpoint of compliance with his presumption of innocence. In other words, when assessing the legality of the payment account closure, the court must ensure that the application of this subjective right by the bank does not violate the relevant constitutional guarantees of the consumer's presumption of innocence (e.g., Article 92 of the Latvian Constitution), taking into account their interpretation following international human rights obligations ${ }^{42}$, including Article 48 (1) of the Charter and Article 6 (2) of the European Convention for the Protection of Human Rights (hereinafter referred to as Convention). In particular, the court has to check whether, by unilateral termination of business relations, the bank has not de facto stigmatised the consumer as a person suspected of involvement in criminal activities by unilateral termination of business relations.

\footnotetext{
${ }^{40}$ Preambular paragraph 66 of Directive (EU) 2015/849.

${ }^{41}$ See, e.g, Latvian Constitutional Court's judgment in case No. 2008-47-01 $\$ 15.9$.

${ }^{42}$ See, e.g., Latvian Constitutional Court's judgment in case No. 2008-09-0106 $§ 4$.
} 


\section{Private Life}

Similarly, if within de-risking the bank unilaterally terminates a legal relationship, the consumer's interests are subject to analysis from the perspective of respect for his right to private life, within the meaning that has been assigned to it by the case-law of the ECHR.

Being a broad term not susceptible to exhaustive definition, "private life" also involves a zone of interaction of a person with others even in a public context that is an essential element of the personal space protected by Article 8 of the Convention ${ }^{43}$. This human right covers the physical and psychological integrity of a person, including multiple aspects of the individual's physical and social identity $^{44}$. Therefore, it can embrace the right to live privately, away from unwanted attention that secures an individual space within which he can freely pursue the development and fulfilment of his or her personality ${ }^{45}$. According to the ECHR's case-law it would be too restrictive to limit the notion of "private life" to an "inner circle" where the individual may live his own personal life as he chooses and to exclude therefrom entirely the outside world not encompassed within that circle $^{46}$. That is why Article 8 of the Convention protects the right to establish and develop relationships with other human beings and the outside world, including elements relating to a person's right to their image ${ }^{47}$. Furthermore, no clear reason is provided why this understanding of "private life" should be taken to exclude activities of a professional or business nature since it is, after all, in the course of their working lives that the majority of people develop a significant, if not the greatest, opportunity of developing relationships with the outside world ${ }^{48}$. Regarding the consequences of illegal interference with private life for the person's "inner circle," the ECHR also ascribes them to the worsening of the material well-being of this individual and his family ${ }^{49}$. Moreover, in the Convention organs' case-law, it has been accepted that a person's right to protect his reputation is also encompassed by Article 8 as part of the right to respect for private life since it forms part of his personal identity and psychological integrity ${ }^{50}$. Within the framework of Article 96 of the Latvian Constitution, the national Constitutional Court's jurisprudence fully supports this doctrine, emphasizing that the right to private life also protects a person's honour and dignity, name, identity, and personal data ${ }^{51}$.

Following this well-established approach, we have every reason to conclude that both the consumer's social identity and his psychological integrity, as well as his right to establish and develop relationships with other people and the outside

\footnotetext{
${ }^{43}$ See Peck v. the United Kingdom $§ 57$.

${ }^{44}$ See Denisov v. Ukraine $§ 95$.

${ }^{45}$ See Taliadorou and Stylianou v. Cyprus $§ 52$.

${ }^{46}$ See Fernández Martínez v. Spain $§ 108$.

${ }^{47}$ See S. and Marper v. United Kingdom $§ 66$.

${ }^{48}$ See Niemietz v Germany $§ 29$.

${ }^{49}$ See Pişkin v. Turkey $\S 185$.

${ }^{50}$ See Pfeifer v. Austria $§ 35$.

${ }^{51}$ See, for example, Latvian Constitutional Court's judgments: in case No. 2016-06-01 $\S 18.1$; in case No. 2015-14-0103 $§ 15.1$.
} 
world, may well become victims of unfairness when perfunctory application of legislative and contractual rules of unilateral closure of a payment account by a bank due to money laundering risks. It is also apparent that by treating a client as a possible or potential criminal, a bank infringes on his honor, dignity, and reputation. Likewise, by depriving the client of access to banking services, the provider damages his professional and business activities as well as his material well-being. Of course, the client's reputation also suffers when as a reason for withdrawing from contractual relations, a bank references so-called "adverse media" ${ }^{, 52}$ and other negative information regarding the client derived from open sources. Thus, all of the above is illegal interference with the private life of the consumer, which is prohibited by Article 8 of the Convention, Article 7 of the Charter and Article 96 of the Latvian Constitution.

Although the purpose of Article 8 of the ECHR is primarily to protect a person from arbitrary interference by state institutions, it not only obliges the state to abstain from any interference with the individual's private life (negative undertaking) but also demands affirmative action from the state to ensure respect for this human right (positive obligation) ${ }^{53}$. Among others, these obligations are to involve the adoption of measures designed to secure respect for private and family life and should include the requirement that the state establish a system for the effective protection of an individual's right to privacy with implementation in cases of unlawful interferences falling within its scope ${ }^{54}$.

As inherent in an effective "respect" for private life, the positive obligations of any EU state may involve the adoption of measures designed both for the provision of a regulatory framework of adjudicatory and enforcement mechanisms protecting individuals' rights and the implementation, where appropriate, of specific individual measures ${ }^{55}$. At the same time, these obligations apply to adopting such measures, which are designed to secure respect for private life even when applied to relations of individuals between themselves ${ }^{56}$. Therein there must be had a fair balance that has to be struck between the relevant competing interests $^{57}$, that, among other things, is the subject of this research.

Consequently, in each such case, the state authorities, including national courts, are obliged to ensure the implementation of specific measures of the judicial and law enforcement mechanism for adequate and effective protection of the inviolability and respect for the private life of the payment service consumer, since this is the state's positive obligation even when illegal interference with private life occurs in the sphere of relations between subjects of private law among themselves.

In the course of termination of a banking services relationship due to a higher risk of money laundering, the consumer's "private life" could be both the reason for the bank's actions (for example, the bank's use of the consumer's personal data,

\footnotetext{
${ }^{52}$ For example, it has been prescribed by paragraph 31.3 of Regulations of the Financial and Capital Market Commission No.5 dated 12 January 2021.

${ }^{53}$ See Pişkin v.Turkey $\S 202$.

${ }^{54}$ See Taliadorou and Stylianou v. Cyprus $§ 49$.

${ }^{55}$ See Tysiąc v. Poland $\S 110$.

${ }^{56}$ See Parfentyev v. Russia $§ 33$.

${ }^{57}$ Ibid.
} 
including negative information) and their consequence, which causes harm to the consumer's rights (for example, depriving the consumer of access to financial services, including the payments system). That is why it seems fairly reasonable for this analysis to combine the ECHR case-law approaches ${ }^{58}$, one of which is based on the identification of the "private life" of a payment service consumer as the reason for the closure of his bank account (reason-based approach), and the second, which deduces the "private life" issue as the negative consequence of such closure (consequence-based approach).

In particular, when the bank bases the termination of business relations with a consumer on negative information concerning him (including "adverse media"), this means that the consumer's personal data ${ }^{59}$, i.e., one of the protected aspects of his private life ${ }^{60}$, serves as grounds for the bank's decision. Moreover, if, under such circumstances, the negative information used by the bank proves to be false, then the honor and dignity of the consumer are also threatened. Still, their inviolability is also an element of the consumer's private life as well. In this matter, the issue is further complicated by the fact that in order to protect public interests related to combating money laundering and terrorist financing, the data subject is not entitled to access the detrimental data collected by the bank about him (e.g., Article 52 (2) of the Latvian AML Law). This means that when his account is closed, the client has no way of refuting or disputing the served as the underlying reason for the bank to withdraw from the contractual relationship with him since this information is not communicated to him and, moreover, is hidden from him within the framework of the legal requirements. In this case, therefore, the bank's good faith is the only safeguard that doubtful and false information about the consumer will not be used to close the account, and, on the contrary, that the consumer will be given a chance to explain or refute the negative information collected by the bank about him.

On the other hand, the bank's unfair actions to unilaterally refuse to provide the consumer with payment service may lead to serious negative effects on the consumer's private life, including a pernicious impact on his "inner circle" (affecting his welfare), his ability "to establish and develop relationships with others," and a derogatory influence on his social and professional reputation ${ }^{61}$. It is obvious that limiting the consumer's access to the system of banking services, as well as depriving him of the opportunity to receive, send and keep non-cash money, can have an extremely negative influence on the personal life of the consumer and his family.

\footnotetext{
${ }^{58}$ See Denisov v. Ukraine § 107; Fernández Martínez v. Spain §§ 110-112.

${ }^{59}$ Under Article 4 (1) of Regulation (EU) 2016/679 personal data means any information relating to an identified or identifiable natural person.

${ }^{60}$ See, for example, Latvian Constitutional Court's judgments in case No. 2016-06-01 § 18.1; in case No. 2015-14-0103 § 15.1.

${ }^{61}$ Herein we are using the ECHR approach, which similarly specifies serious negative effects on the individual's professional life that are covered with Article 8 of the Convention in so far as these violations have or may have a serious negative impact on the individual's private life (see, for example, Denisov v. Ukraine, no. 76639/11, § 107).
} 
Since non-cash money is incorporeal things or intangible property (res incorporates) ${ }^{62}$, namely, obligation rights (claims) of the client against the bank (records in the bank's accounting system regarding the deposit on the client's account), then possession, exercise, and disposal of them without the participation of the bank is impossible. The disposal of non-cash money (non-cash payments) is, in fact, the transfer of the obligation rights (claims) against the bank from the former creditor (payer) in favour of a new one (payee) that is, on the whole, governed by the civil law provisions regarding cession (assignment of rights) ${ }^{63}$ but not by rules of ownership ${ }^{64}$. Strictly speaking, non-cash money, like any other incorporeal thing, cannot per se be the subject of ownership, but the exercise of any client's rights in respect to them ultimately depends on the bank's positive actions in the form of payment services. Accordingly, in the absence of a contractual relationship with the bank, the client is unable to possess, use and dispose of non-cash money, which, in the context of the modern state policy to limit the circulation of cash and the current state of civil circulation, detrimentally affects the client's "private life" in a significant way. Among other things, as long as the unbanked person, due to de-risking policy, is deprived of any way from receiving and making non-cash payments within civil transactions, his participation in legal relations with other people is hugely complicated and may cause severe damage to his material welfare and reputation.

Regarding the restrictions (interference) of the consumer's human right to private life permitted by Article 8 (2) of the Convention and Article 96 of the Latvian Constitution (to prevent disorder or crime, to protect health, morals, or to protect the rights and freedoms of others), then, with reference to the above analysis of the legitimacy of aims and the proportionality of such restrictions for the presumption of innocence, we should note that such restrictions may be justified when conducting due diligence measures concerning the consumer and supervising his transactions in the normal course of business relations (e.g., as prescribed by Article 11-1 of the Latvian AML law), but only up to the point when such restrictions result in a unilateral withdrawal of the bank from above business relationships. If the latter is the case, both the legitimate aim of these restrictions and the reasonable necessity of the bank's intervention in the consumer's private life are not respected. Moreover, such behavior on the part of the bank destroys the balance between public interests and the consumer's human rights.

It is also clear that each case requires a dedicated analysis addressing the gravity of the negative effect of interference with privacy for every individual, with the specific circumstances taken into consideration. It is necessary to assess to what extent, due to the closure of a bank account, a person's opportunities in his private life scope decreased, whether psychological aftermath was significant for him, how his life quality and relations with other people deteriorated, how seriously the termination of business relations with the bank affected the consumer's material well-being, etc. The damage caused to the individual's interests and suffering is to

\footnotetext{
${ }^{62}$ See, for example, Article 841 (2) of Latvian Civil Law that received this concept from the Roman law.

${ }^{63}$ Balodis (2007) at 111.

${ }^{64}$ Grūtups \& Kalniņš (2002) at 20.
} 
be assessed by comparing his life before and after the break of contractual relations with the bank. At the same time, it is appropriate to consider the subjective perceptions of the consumer against the background of the objective circumstances existing in the particular case. This analysis would have to cover both the material and the non-material impact of the termination of the consumer's access to banking services, that should simultaneously have a causal connection with the impugned actions of the bank ${ }^{65}$.

From apportionment of the evidential burdens between civil process parties (ei incumbit probatio qui dicit, non qui negat - proof lies on him who asserts, not on him who denies) ${ }^{66}$, it follows that it is the consumer who must establish convincingly that the threshold of severity with respect to damage for all the above-mentioned aspects of his private life was attained in his case. He has to present evidence substantiating the consequences of the bank's unfair actions, which will be only applicable where these consequences are extremely grave and affect his private life to a very significant degree ${ }^{67}$.

Overall, it is important to stress that the payment service consumer involved in a commission of a criminal offence or other such misconduct, and subsequently cut off by the bank, cannot rely on the foreseeable negative effects on "private life" 68 when appealing a unilateral termination of contractual relations. $y$. Consequently, even if the bank, when terminating the contract, has acted in violation of the good faith principle, it may protect itself from negative consequences and may legally refuse to restore contractual relations with a client by proving that the account closure came as a predictable consequence of the client's misconduct or any other inappropriate actions, which are directly or indirectly related to money laundering or financing of terrorism ${ }^{69}$.

\footnotetext{
${ }^{65}$ This approach is based on criteria for assessing the severity or seriousness of alleged violations of Article 8 of the Convention in different regulatory contexts that the ECHR has established (see, for example, Denisov v. Ukraine, no. 76639/11, § 117).

${ }^{66}$ See, for example, Līcis (2003) at 72.

${ }^{67}$ See, e.g., Denisov v. Ukraine $§ 116$.

${ }^{68}$ Following the case-law of the ECHR, it is necessary to indicate that Article 8 cannot be relied on in order to complain of a loss of reputation, which is the foreseeable consequence of one's own actions such as, for example, the commission of a criminal offence (see, e.g., Sidabras and Džiautas v. Lithuania § 49). In the Court's view, other personal, social, psychological and economic suffering may also be foreseeable consequences of the commission of a criminal offence and can therefore not be used as a ground to complain that a criminal conviction in itself amounts to an interference with the right to respect for "private life" within the meaning of Article 8 of the Convention (see, for example, Gillberg v. Sweden § 68). This extended principle should cover not only criminal offences but also other misconduct entailing a measure of legal responsibility with foreseeable negative effects on "private life" (see, e.g., Pişkin v. Turkey § 178).

${ }^{69}$ As one of the founders of the Latvian interwar period civil procedural law doctrine, Vladimirs Bukovskis pointed out that in claims arising from unallowed actions or negligence, "If the claimant has proved that the defendant has acted for evil purposes, the defendant may remedy the consequences of such evidence by demonstrating that the claimant has also acted for evil purposes" (Bukovskis (2015) at 775). We believe that this proof formula can reasonably be extended to the above issues when invoking the principle of good faith.
} 


\section{Conclusions}

In summary, we can conclude that following the purpose of the law, public interests, the objective specifics of the contractual parties' legal status and the entire complex of legal regulation as well as in view of systemic and teleological interpretation of governing legal rules, in cases of unilateral closure of payment accounts by banks due to de-risking, the conflicting interests of consumers have priority in their legal protection. This precedence should survive until it is proven that the consumer acted unlawfully or was otherwise implicated in money laundering and terrorist financing.

Imposition on the consumers' fundamental rights may be considered justifiable to preclude money laundering for preventive purposes as long as the consumers' contractual relationship with the bank continues. But in the case of unilateral closure of payment account by a bank, only strict adherence to the good faith principle can guarantee that the bank's subjective right to withdraw from the agreement unilaterally is not used formally and unreasonably. Otherwise, the bank's abstract application of the terms of an "undiscussed" contract and the effect from the formal exercise of the bank's subjective rights may become absolutely unfair to the discarded consumer.

Therefore, taking into account the circumstances of each dispute, including the objective consequences of closing an account for the life of every specific consumer, the contractual terms and the bank's actions must be assessed for their compliance with the good faith requirements, which in turn should be recognised not only as permissible but also obligatory. When terminating contractual relations within de-risking, only close adherence to the good faith principle can guarantee that the bank's rights are not used by the bank formally and unreasonably, that is, against the regulating sense, meaning, and goals or contrary to the general idea of law.

\section{References}

Apse, D. (2006). 'Auxiliary Sources of Law and the Constitutional Court" in Scientific Papers University of Latvia 703:7-20 [in Latvian].

Apse, D. (2012). 'The influence of subsidiary sources of law on the quality of legal acts in the legislative process and the system of national governance' in The collection of research papers in conjunction with the international scientific conference "The Quality of Legal Acts and its Importance in Contemporary Legal Space”, pp.56-68. Riga: University of Latvia Press.

Apsìts, H. (1938). 'The New Civil Law' in Prezidenta Ulmaña Civillikums. Rakstu kräjums, p.85. Riga: Pagalms [in Latvian].

Balodis, K. (2002). "The role of the principle of good faith in modern Latvian civil law" in Likums un Tiesības, Volume 4, Nr.9(37):279.-286 [also in Jurista Vārds, 3. Dec. 2002, Nr. 24 (257)] [in Latvian].

Balodis, K. (2007). Introduction to Civil Law. Rīga: Zvaigzne ABC [in Latvian].

Berent, B., Ehlers, H., Blaese, G., Schilling, C. \& Th. Zimmermann (1938). Lettlands Zivilgesetzbuch. of 28 January 1937 in Einzeldarstellungen. Riga: Verlag A/G "Ernst Plates" 
Brazowski, J. (2019). 'Risks in the financial sector must be managed, not abandoned' (in Latvian) in TVNET / LETA, 07.10.2019

Brox, H. \& W. Walker (2010). Allgemeiner Teil des BGB. 34. München: Carl Heymanns Verlag.

Brox, H. \& W. Walker (2020). Allgemeines Schuldrecht. 44. Aufl. München: Verlag C.H. Beck.

Bukovskis, V. (1933). Textbook on Civil procedure. Riga, reissued in 2015. [in Latvian\}

Durner, T. \& L. Shetret (2015). Undersbanding bank de-risking and its effects on financial inclusion. An exploratory study, Global Center on Cooperative Security. https:// www-cdn.oxfam.org/s3fs-public/file_attachments/rr-bank-de-risking-181115-en_0. pdf

Eckert, J. (2004). Schuldrecht: Allgemeiner Teil 4. Baden-Baden: Nomos.

FATF (2014) clarifies risk-based approach: case-by-case, not wholesale de-risking. Paris, 23 October at www.fatf-gafi.org/documents/documents/rba-and-de-risking.html

Grūtups, A. \& E. Kalniņš (2002). Comments on Civil Law, Part Three, Property Law, Property. $2^{\text {nd }}$ ed. Riga: Tiesu namu aǵentūra [in Latvian].

Hartkamp, A., Hesselink, M., Hondius, E. \& E. Perron (2010). Towards a European Civil Code. 4th edition. Boston: Kluwer Law International.

Iljanova (Rezevska), D. (2005). Meaning and application of general principles of law. Riga: Ratio iuris [in Latvian].

Jelisejevs, A. (2021). 'Good Faith-Based Approach as a way to protect payment service consumers' rights when banks unilaterally terminate contractual relations' in Collection of materials XXII International Scientific Conference of Turiba University, pp. 59-67.

Karinšs, K. (2020). 'The Latvian financial sector must reorient to risk management, not just avoid risks' (in Latvian) in Delfti Bizzness, September 9.

Kazāks, M. (2020). 'There are more pros than cons of the FCMC merging with the Bank of Latvia' (in Latvian) in Delfti Bizzness, January 3.

De Koker, L., Sindh, S. \& J. Capal (2017). 'Closure of bank accounts of remittance service providers: Global challenges and community perspectives in Australia' in University of Queensland Law Journal 36 (1):119-154.

De Koker, L. (2011). 'Aligning anti-money laundering, combating of financing of terror and financial inclusion: questions to consider when FATF standards are clarified' in Journal of Financial Crime 18(4): 361-386.

Krons, M. (1937). 'Article 1 of the Civil Law (Good faith as a lawful conduct criterion)' in Tieslietu ministrijas Vēstnesis. Gulbja grāmatu izdevniecība, pp.270-301. Nr.2 Riga [in Latvian].

Kull, I. (2004). 'European and Estonian Law of Obligations - Transposition of Law or Mutual Influence?' in Juridica International IX:32-44//2004. University of Tartu.

Larenz, K. (1987). Lehrbuch des Schuldrechts Band I Allgemeiner Teil. 14.th ed. München: Verlag C.H. Beck.

Larenz, K. \& M. Wolf (2016). Allgemeiner Teil des Bürgerlichen Rechts. 11th ed. München: Verlag Beck C. H.

Līcis, A. (2003). Claims in legal proceedings and evidence. Riga: Tiesu namu aǵentūra [in Latvian].

McKendry, I. (2014). Banks Face No-Win Scenario on AML 'De-Risking'. In: American Banker, 17 November.

Neimanis, J. (2004). Introduction to Law. Riga [in Latvian].

Rezevska, D. (2015). Meaning and application of general principles of law. 2nd edition, revised and expanded. Riga: Daiga Rezevska [in Latvian]. 
Vol. 7, No. $4 \quad$ Jelisejevs: Crucial Issues with Legal Protection of Consumers Human...

Roth, G. (2015). Münchener Kommentar zum Bürgerlichen Gesetzbuch Bd. 2, Schuldrecht Allgemeiner Teil. München.

Schulze, R. (2017). In: Bürgerliches Gesetzbuch, Handkommentar. 9th ed. Baden-Baden.

Slicāne, E. (2007). 'The principle of good faith and its application in Latvian civil law' in Jurista Vārds 6(459) [in Latvian].

Schmidt, R. (2019). BGB Allgemeiner Teil. 18th ed. Schmidt, Dr. Rolf Verlag.

Szubin, A. (2016). Remarks by Acting Under Secretary Adam Szubin [USA] at the ABA/ ABA Money Laundering Enforcement Conference. Washington, 14.11.2016. https:// www.treasury.gov/press-center/press-releases/Pages/j10608.aspx

Vītoliņa, B. (2015). Basics of consumer protection. Riga: Apgāds Zvaigzne ABC [in Latvian].

Wilkins, R. (2014). 'The danger of driving both illicit markets and financial exclusion' at http://www.fatf-gafi.org/topics/fatfgeneral/documents/danger-illicit-marketsfinancial-exclusion.html

\section{Cases}

\section{European Court of Justice}

Elisa María Mostaza Claro v. Centro Móvil Milenium SL, C-168/05, ECLI:EU:C:2006: 675, 26 October 2006.

Océano Grupo Editorial SA v. Rocío Murciano Quintero (C-240/98) and Salvat Editores SA v. José M. Sánchez Alcón Prades (C-241/98), José Luis Copano Badillo (C-242/ 98), Mohammed Berroane (C-243/98), Emilio Viñas Feliu (C-244/98), ECLI:EU: C:2000:346, 27 June 2000.

Pannon GSM Zrt. v. Erzsébet Sustikné Győrfi, C-243/08, ECLI:EU:C:2009:350, 4 June 2009.

\section{European Court of Human Rights (ECHR)}

Denisov v. Ukraine, no. 76639/11, ECHR 25 September 2018

Fernández Martínez v. Spain, no. 56030/07, ECHR 12 June 2014

Gillberg v. Sweden, no.41723/06, ECHR 3 April 2012

Niemietz v. Germany, no. 13710/88, A/251-B, ECHR 16 December 1992

Parfentyev v. Russia, no. 44376/09, ECHR 3 November 2020

Peck v. the United Kingdom, no. 44647/98, ECHR 28 April 2003

Pfeifer v. Austria, no. 12556/03, ECHR 15 November 2007

Pişkin v. Turkey, no. 33399/18, ECHR 15 December 2020

S. and Marper v. United Kingdom, no. 30562/04 and no. 30566/04, ECHR 4 December 2008

Sidabras and Džiautas v. Lithuania, no. 55480/00 and no. 59330/00, ECHR 27 June 2004

Taliadorou and Stylianou v. Cyprus, no. 39627/05 and no. 39631/05, ECHR 16 October 2008

Tysiąc v. Poland, no. 5410/03, ECHR 20 March 2007 


\section{Constitutional Court of the Republic of Latvia}

Judgment of 23 February 2006 in case No. 2005-22-01. Latvijas Vēstnesis, 28.02.2006., Nr. 34.

Judgment of 16 December 2008 in case No. 2008-09-0106. In: Latvijas Vēstnesis, 18.12.2008., Nr. 197.

Judgment of 28 May 2009 in case No. 2008-47-01. Latvijas Vēstnesis, 02.06.2009., Nr. 85.

Judgment of 27 December 2010 in case No. 2010-38-01. In: Latvijas Vēstnesis, 30.12.2010, Nr 206.

Judgment of 28 March 2013 in case No. 2012-15-01. Latvijas Vēstnesis, 02.04.2013., Nr. 63.

Judgment of 12 May 2016 in case No.2015-14-0103. Latvijas Vēstnesis, 13.05.2016., Nr. 92.

Judgment of 15 November 2016 in case No.2015-25-01. Latvijas Vēstnesis, 16.11.2016., Nr. 224.

Judgment of 10 February 2017 in case No. 2016-06-01. Latvijas Vēstnesis, 13.02.2017., Nr. 33.

\section{Department for Administrative Cases of the Supreme Court Senate}

Judgment of 7 March 2006 in case No. SKC-59.

\section{Department for Civil Cases of the Supreme Court Senate}

Judgment of 9 February 2005 in case No. SKC-75. https://at.gov.lv/downloadlawfile/3533

Judgment of 4 October 2006 in case No. SKC-540. https://www.at.gov.lv/downloadlawfi le/3475

Judgment of 30 June 2017 in case No. C33439211, SKC-154/2017. https://at.gov.lv/down loadlawfile $/ 5210$

Judgment of 27 October 2017 in case No. C09020614, SKC-363/2017, ECLI:LV:AT: 2017: 1027.C09020614.1.S.

Judgment of 18 December 2018 in case No. C73346818, SKC-1782/2018, ECLI:LV: T: 2018: 1218.C73346818.10.S.

Judgment of 17 December 2019 in case No. C04169414, SKC-259/2019, ECLI:LV:AT: 2019: 1217.C04169414.5.S.

Judgment of 12 March 2020 in case No. C68278418, SKC-189/2020, ECLI:LV:AT:2020: 0312.C68278418.8.S.

Judgment of 16 December 2020 in case No. C30501917, SKC-231/2020, ECLI:LV:AT: 2020:1216.C30501917.11.S. 
Vol. 7, No. $4 \quad$ Jelisejevs: Crucial Issues with Legal Protection of Consumers Human...

\section{United Kingdom}

Dahabshiil Transfer Services Ltd v Barclays Bank Plc (Case No. HC13E04264), [2013] EWHC 4196 (Ch)

Harada Ltd and another v Barclays Bank Plc. (Case No. HC13E04616), [2013] EWHC $3379(\mathrm{Ch})$

\section{Legal Instruments}

Charter of Fundamental Rights of the European Union (2012/C 326/02) in Official Journal of the European Union, 26.10.2012, Vol. 55, p. 391

Civil Law of the Republic of Larvia in Valdības Vēstnesis, 20.02.1937, No.41

Constitution of the Republic of the Republic of Latvia

Consumer Rights Protection Law of the Republic of Latvia in Latvijas Vēstnesis, 01.04.1999., No.104/105

Directive (EU) 2015/2366 of the European Parlament and of the Council of 25 November 2015 on payment services in the internal market, amending Directives 2002/65/EC, 2009/110/EC and 2013/36/EU and Regulation (EU) No 1093/2010, and repealing Directive 2007/64/EC, in Official Journal of the European Union, 23.12.2015, Vol. 58, p. 35

Directive 2014/92/EU of the European Parliament and of the Council of 23 July 2014 on the comparability of fees related to payment accounts, payment account switching and access to payment accounts with basic features, in Official Journal of the European Union, 28.08.2014, Vol. 57, p.214

Directive 2014/92/EU of the European Parliament and of the Council of 23 July 2014 on the prevention of the use of the financial system for the purposes of money laundering or terrorist financing, amending Regulation (EU) No 648/2012 of the European Parliament and of the Council, and repealing Directive 2005/60/EC of the European Parliament and of the Council and Commission Directive 2006/70/EC, in Official Journal of the European Union, 05.06.2015, Vol.58, p.73

European Convention on Human Rights (as amended by the provisions of Protocol No. 14, CETS No. 194)

Law on Payment Services and Electronic Money of the Republic of Latvia in Latvijas Vēstnesis, 17.03.2010, No. 43

Law on the Prevention of Money Laundering and Terrorism and Proliferation Financing of the Republic of Latvia in Latvijas Vēstnesis, 30.07.2008., No. 116

Personal Data Processing Law of the Republic of Latvia in Latvijas Vēstnesis, 04.07.2018, No.132

Regulation (EU) 2016/679 of the European Parliament and of the Council of 27 April 2016 on the protection of natural persons with regard to the processing of personal data and on the free movement of such data, and repealing Directive 95/46/EC (General Data Protection Regulation) in Official Journal of the European Union, 04.05.2016, Vol. 59, p.1

Regulations of the Financial and Capital Market Commission of the Republic of Latvia No.5 dated 12 January 2021, in Latvijas Vēstnesis, 18.01.2021, No.11 